\title{
Front Matter: Volume 7162
}

, "Front Matter: Volume 7162," Proc. SPIE 7162, Lasers in Dentistry XV, 716201 (9 March 2009); doi: 10.1117/12.827217

SPIE. Event: SPIE BiOS, 2009, San Jose, California, United States 


\section{PROGRESS IN BIOMEDICAL OPTICS AND IMAGING}

Vol. 10, No. 2

\section{Lasers in Dentistry XV}

Peter Rechmann

Daniel Fried

Editors

24 January 2009

San Jose, California, United States

Sponsored and Published by

SPIE

Volume 7162 
The papers included in this volume were part of the technical conference cited on the cover and title page. Papers were selected and subject to review by the editors and conference program committee. Some conference presentations may not be available for publication. The papers published in these proceedings reflect the work and thoughts of the authors and are published herein as submitted. The publisher is not responsible for the validity of the information or for any outcomes resulting from reliance thereon.

Please use the following format to cite material from this book:

Author(s), "Title of Paper," in Lasers in Dentistry XV, edited by Peter Rechmann, Daniel Fried, Proceedings of SPIE Vol. 7162 (SPIE, Bellingham, WA, 2009) Article CID Number.

ISSN 1605-7422

ISBN 9780819474087

Published by

SPIE

P.O. Box 10, Bellingham, Washington 98227-0010 USA

Telephone +1 3606763290 (Pacific Time) · Fax +1 3606471445

SPIE.org

Copyright @ 2009, Society of Photo-Optical Instrumentation Engineers.

Copying of material in this book for internal or personal use, or for the internal or personal use of specific clients, beyond the fair use provisions granted by the U.S. Copyright Law is authorized by SPIE subject to payment of copying fees. The Transactional Reporting Service base fee for this volume is $\$ 18.00$ per article (or portion thereof), which should be paid directly to the Copyright Clearance Center (CCC), 222 Rosewood Drive, Danvers, MA 01923. Payment may also be made electronically through CCC Online at copyright.com. Other copying for republication, resale, advertising or promotion, or any form of systematic or multiple reproduction of any material in this book is prohibited except with permission in writing from the publisher. The CCC fee code is 1605$7422 / 09 / \$ 18.00$.

Printed in the United States of America.

Publication of record for individual papers is online in the SPIE Digital Library.

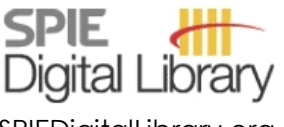

SPIEDigitalLibrary.org

Paper Numbering: Proceedings of SPIE follow an e-First publication model, with papers published first online and then in print and on CD-ROM. Papers are published as they are submitted and meet publication criteria. A unique, consistent, permanent citation identifier (CID) number is assigned to each article at the time of the first publication. Utilization of CIDs allows articles to be fully citable as soon they are published online, and connects the same identifier to all online, print, and electronic versions of the publication. SPIE uses a six-digit CID article numbering system in which:

- The first four digits correspond to the SPIE volume number.

- The last two digits indicate publication order within the volume using a Base 36 numbering system employing both numerals and letters. These two-number sets start with 00, 01, 02, 03, 04, $05,06,07,08,09,0 A, 0 B \ldots$. OZ, followed by 10-1Z, 20-2Z, etc.

The CID number appears on each page of the manuscript. The complete citation is used on the first page, and an abbreviated version on subsequent pages. Numbers in the index correspond to the last two digits of the six-digit CID number. 


\section{Contents}

vii Conference Committee

\section{SESSION 1 LASERS IN DENTAL HARD TISSUE}

716203 A comparison of terahertz-pulsed imaging with transverse microradiography and microhardness to measure mineral changes in enamel after treatment with fluoride dentifrices (Invited Paper) [7162-01]

D. Churchley, F. Lippert, R. Lynch, GlaxoSmithKline (United Kingdom); J. Alton, TeraView Ltd. (United Kingdom); C. Gonzalez-Cabezas, J. Eder, Oral Heath Research Institute, Indiana School of Dentistry (United States)

716205 Early detection of tooth wear by en face optical coherence tomography [7162-03] C. Mărcăuțeanu, M. Negruțiu, C. Sinescu, E. Demjan, Univ. of Medicine and Pharmacy "Victor Babes" (Romania); M. Hughes, A. Bradu, G. Dobre, A. Gh. Podoleanu, Univ. of Kent (United Kingdom)

716206 Ex vivo imaging of early dental caries within the interproximal space [7162-04] L.-P. Choo-Smith, M. D. Hewko, M. L. Dufour, C. Fulton, P. Qiu, B. Gauthier, C. Padioleau, C.-E. Bisaillon, National Research Council Canada (Canada); C. Dong, Univ. of Manitoba (Canada); B. M. Cleghorn, Dalhousie Univ. (Canada); G. Lamouche, M. G. Sowa, National Research Council Canada (Canada)

$716208 \mathbf{2 4} \mathbf{~ m m}$ depth range discretely swept optical frequency domain imaging in dentistry [7162-07]

H. Kakuma, Yoshida Dental Mfg. Co., Ltd. (Japan); D. Choi, H. Furukawa, H. Hiro-Oka, K. Ohbayashi, Kitasato Univ. (Japan)

716209 Time-course diffusion of hydrogen peroxide using modern technologies [7162-08] F. L. E. Florez, São Paulo State Univ. (Brazil); J. D. Vollet-Filho, Univ. of São Paulo (Brazill);

O. B. Oliveira-Junior, São Paulo State Univ. (Brazil); V. S. Bagnato, Univ. of São Paulo (Brazil)

SESSION 2 LASERS IN ENDODONTICS, ORTHODONTICS, PERIODONTOLOGY, BLEACHING, AND CARIES PREVENTION

$7162 \mathrm{OB}$ Morphological changes of the root surface and fracture resistance after treatment of root fracture by $\mathrm{CO}_{2}$ laser and glass ionomer or mineral trioxide aggregates [7162-19] Y. A. Badr, L. M. Abd El-Gawad, M. E. Ghaith, Cairo Univ. (Egypt)

7162 0C Laser brackets debonding: Im:YAP, Nd:YAG, and GaAs diode lasers evaluation [7162-20] T. Dostálová, Charles Univ. (Czech Republic); H. Jelínková, J. Šulc, P. Koranda, M. Nĕmec, Czech Technical Univ. (Czech Republic); I. Ivanov, Charles Univ. (Czech Republic); M. Miyagi, K. Iwai, Sendai National College of Technology (Japan) 
$71620 \mathrm{E} \quad$ Laser ablation of dental calculus at $\mathbf{4 0 0} \mathbf{n m}$ using a Ti:sapphire laser [7162-22]

J. E. Schoenly, W. Seka, Univ. of Rochester (United States) and Institute of Optics, Univ. of Rochester (United States); P. Rechmann, Univ. of California, San Francisco (United States)

7162 OF Dentin bond strength after ablation using a $\mathrm{CO}_{2}$ laser operating at high pulse repetition rates [7162-23]

S. Hedayatollahnajafi, M. Staninec, L. Watanabe, C. Lee, D. Fried, Univ. of California, San Francisco (United States)

$71620 \mathrm{G}$ Comparative assessment of the organization of the colors of the Vita Classical color pallet by digital images and visual analysis for dental bleaching [7162-24]

O. B. Oliveira-Júnior, M. S. Cioffi, R. M. Cesnik, São Paulo State Univ. (Brazil); F. L. E. Florez,

V. S. Bagnato, Univ. of São Paulo (Brazil); D. R. Corrêa-dos-Santos, F. P. Fornazari, Faculdades Logatti Araraquara (Brazil)

$7162 \mathrm{OH} \quad$ Inhibition of enamel remineralization with blue LED: an in vitro study [7162-25]

I. T. Kato, Instituto de Pesquisas Energéticas e Nucleares (Brazil); F. M. Mendes, Univ. de São Paulo (Brazil); D. M. Zezell, A. Zanardi de Freitas, M. P. Raele, N. U. Wetter, Instituto de Pesquisas Energéticas e Nucleares (Brazil)

\section{POSTER SESSION A}

$71620 \mathrm{~J}$ Tooth whitening and temperature rise with two bleaching activation methods [7162-10] D. M. Abu-ElMagd, I. I. El-Sayad, L. M. Abd El-Gawad, Cairo Univ. (Egypt)

$71620 \mathrm{~K}$ In vitro study of the influence of the pigments of three colored gels over the light distribution of visible light by digital images [7162-11]

F. L. E. Florez, A. C. R. Figueiredo, São Paulo State Univ. (Brazil); L. T. Moriyama, Univ. de São Paulo (Brazil); O. B. Oliveira Junior, São Paulo State Univ. (Brazil); V. S. Bagnato, Univ. de São Paulo (Brazil)

$7162 \mathrm{OL} \quad$ Oral pathology follow-up by means of micro-Raman spectroscopy on tissue and blood serum samples: an application of wavelet and multivariate data analysis [7162-12] I. Delfino, Univ. della Tuscia (Italy); C. Camerlingo, Istituto di Cibernetica, CNR (Italy); F. Zenone, Univ. Federico II (Italy); G. Perna, V. Capozzi, Univ. di Foggia (Italy); N. Cirillo, G. M. Gaeta, E. De Mol, M. Lepore, Seconda Univ. di Napoli (Italy)

\section{POSTER SESSION B}

7162 OS Study on calcifying treatments of hydroxyapatite (HAp) using calcifying promotion solution [7162-29]

M. Wakaki, S. Yazaki, Tokai Univ. (Japan); Y. Sunada, Oji Cornstarch Co., Ltd (Japan)

7162 OT An automated digital microradiography system for assessing tooth demineralization [7162-30]

C. L. Darling, C. Q. Le, J. D. B. Featherstone, D. Fried, Univ. of California, San Francisco (United States) 
7162 OU Methods for calculating the severity of demineralization on tooth surfaces from PS-OCT scans [7162-31]

M. H. Le, C. L. Darling, D. Fried, Univ. of California, San Francisco (United States)

$71620 \mathrm{~V} \quad$ Non-destructive measurement of demineralization and remineralization in the occlusal pits and fissures of extracted $3^{\text {rd }}$ molars with PS-OCT [7162-32]

C. Lee, D. J. Hsu, M. H. Le, C. L. Darling, D. Fried, Univ. of California, San Francisco (United States)

7162 OW Assessment of dentin remineralization with PS-OCT [7162-33]

S. K. Manesh, C. L. Darling, D. Fried, Univ. of California, San Francisco (United States)

7162 OX Near-IR multi-modal imaging of natural occlusal lesions [7162-34]

D. Lee, D. Fried, C. L. Darling, Univ. of California, San Francisco (United States)

Author Index 
Downloaded From: https://www.spiedigitallibrary.org/conference-proceedings-of-spie on 26 Apr 2023

Terms of Use: https://www.spiedigitallibrary.org/terms-of-use 


\title{
Conference Committee
}

\author{
Symposium Chairs \\ James G. Fujimoto, Massachusetts Institute of Technology (United \\ States) \\ R. Rox Anderson, Wellman Center for Photomedicine, Massachusetts \\ General Hospital (United States) and Harvard School of Medicine \\ (United States)
}

Program Track Chair

Reza S. Malek, Mayo Clinic (United States)

Conference Chairs

Peter Rechmann, University of California, San Francisco (United States)

Daniel Fried, University of California, San Francisco (United States)

Program Committee

Gregory B. Altshuler, Palomar Medical Technologies, Inc. (United States)

Tatjána Dostálová, Charles University in Prague (Czech Republic)

John D. B. Featherstone, University of California, San Francisco (United States)

David M. Harris, Bio-Medical Consultants, Inc. (United States)

Harvey A. Wigdor, Advocate Illinois Masonic Medical Center (United States)

\section{Session Chairs}

1 Lasers in Dental Hard Tissue

Peter Rechmann, University of California, San Francisco (United States)

2 Lasers in Endodontics, Orthodontics, Periodontology, Bleaching, and Caries Prevention

Daniel Fried, University of California, San Francisco (United States) 
Downloaded From: https://www.spiedigitallibrary.org/conference-proceedings-of-spie on 26 Apr 2023

Terms of Use: https://www.spiedigitallibrary.org/terms-of-use 